\title{
A New Guide to Thermally Optimized Doped Oxides Monolayer Spray-Grown Solar Cells: The Amlouk-Boubaker Optothermal Expansivity $\psi_{\mathrm{AB}}$
}

\author{
M. Benhaliliba ${ }^{1}$, C.E. Benouis ${ }^{1}$, \\ K. Boubaker2, M. Amlouk ${ }^{2}$ and A. Amlouk ${ }^{2}$ \\ ${ }^{1}$ Physics Department, Sciences Faculty, Oran University of Sciences and Technology \\ Mohamed Boudiaf- USTOMB, POBOX 1505 Mnaouer- Oran, \\ ${ }^{2}$ Unité de Physique des dispositifs à Semi-conducteurs UPDS, \\ Faculté des Sciences de Tunis, Campus Universitaire 2092 Tunis, \\ ${ }^{1}$ Algeria \\ ${ }^{2}$ Tunisia
}

\section{Introduction}

PVC Photovoltaic solar cells are unanimously recognized to be one of the alternative renewable energy sources to supplement power generation using fossils. It is also recognized that semiconductors layered films technology, in reducing production costs, should rapidly expand high-scale commercialization.

Despite the excellent achievements made with the earliest used materials, it is also predicted that other materials may, in the next few decades, have advantages over these front-runners. The factors that should be considered in developing new PVC materials include:

- $\quad$ Band gaps matching the solar spectrum

- Low-cost deposition/incorporation methods

- Abundance of the elements

- Non toxicity and environmental concerns,

Silicon-based cells as well as the recently experimented polymer and dye solar cells could hardly fit all these conditions. Transparent conducting oxides as $\mathrm{ZnO}, \mathrm{SnO}_{2}$ as well as doped oxides could be good alternative candidates.

In this context, the optothermal expansivity is proposed as a new parameter and a guide to optimize the recently implemented oxide monolayer spray-grown solar cells.

\section{Solar cells technologies and design recent challenges}

In spite of better performance of traditional junction-based solar cells, during the past few decades, reports have appeared in literature that describe the construction of cells based metal-oxides (Bauer et al., 2001; Sayamar et al., 1994; He et al., 1999; Tennakone et al., 1999; 
Bandara \& Tennakone, 2001) and composite nanocrystalline materials (Palomares et al., 2003; Kay \& Gratzel, 2002). Since that time, several other semiconductors have been tested with less success.

Recent challenges concerning newly designed solar cells are namely Band-gap concerns, cost, abundance and environmental concerns.

\subsection{Band gaps matching the solar spectrum}

The recently adopted layered structure of PVC raised the problem of solar spectrum matching (Fig.1) as well as lattice mismatch at early stages. In fact, the heterogeneous structure: Contact/window layer/buffer layer/Contact causes at least three differently structured surfaces to adhere under permanent constraints. It is known that the electronic band gap is the common and initial choice-relevant parameter in solar cells sensitive parts design. It is commonly defined as the energy range where no electron states exist. It is also defined as the energy difference between the top of the valence band and the bottom of the conduction band in semiconductors. It is generally evaluated by the amount of energy required to free an outer shell electron the manner it becomes a mobile charge carrier. Since the band gap of a given material determines what portion of the solar spectrum it absorbs, it is important to choose the appropriate compound matching the incident energy range. The choice of appropriated materials on the single basis of the electronic band gap is becoming controversial due the narrow efficient solar spectrum width, along with new thermal and mechanical requirements. It is rare to have a complete concordance between adjacent crystalline structures particularly in band gap sense.

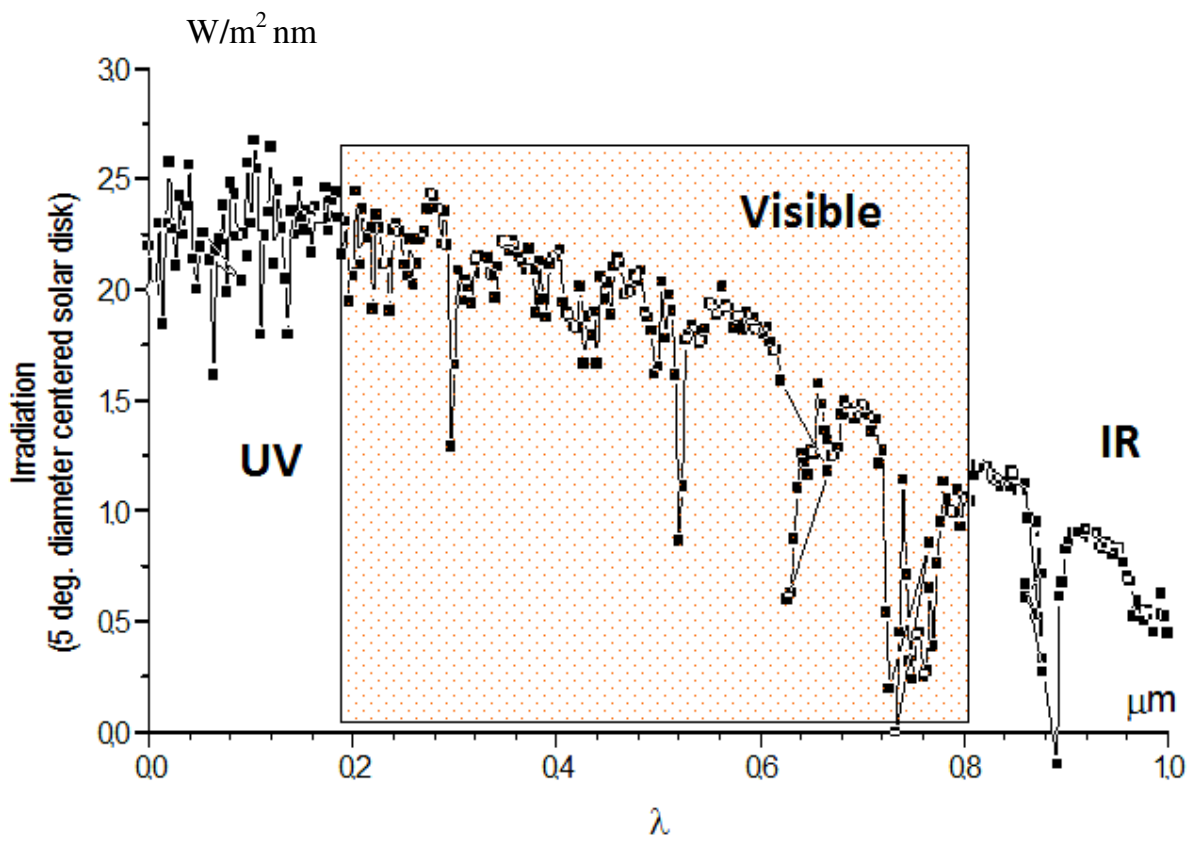

Fig. 1. Solar spectrum 
For example, in silicon-based solar cells, recombination occurring at contact surfaces at which there are dangling silicon bonds ( $\mathrm{Wu}, 2005)$ is generally caused by material/phase discontinuities. This phenomenon limits cell efficiency and decreases conversion quality.

\subsection{Low-cost deposition/incorporation methods}

Deposition techniques and incorporation methods have been developed drastically and several deposition improved methods have been investigated for fabrication of solar cells at high deposition rates $(0.9$ to $2.0 \mathrm{~nm} / \mathrm{s})$, such as hot wire CVD, high frequency and microwave PECVD, , and expanding thermal plasma CVD. Parallel to these improvements, vacuum conditions and chemical processes cost increased the manner that serial fabrication becomes sometimes limited. Nowadays, it is expected that low processing temperature allow using a wide range of low-cost substrates such as glass sheet, polymer foil or metal. These features has made the second-generation low- cost metal-oxides thin-film solar cells promising candidates for solar applications.

\subsection{Abundance of the elements}

The first challenge for PV cells designer is undoubtedly the abundance of materials for buffer and window layers. The ratio of abundance i. e. of Tungsten-to-Indium is around 104, that of of Zinc-to-Tin is around 40. Although efficiency of Indium and Gallium as active doping agents has been demonstrated and exploited (Abe \& Ishiyama, 2006; Lim et al., 2005), their abundance had decreased drastically (510 and 80 tons, respectively as reported by U.S. Geological Survey 2008) with the last decades' exploitation.

\subsection{Non toxicity and environmental concerns}

Among materials being used, cadmium junctions (Cd) and selenium (Se) are presumed to cause serious health and environmental problems. Risks vary considerably with concentration and exposure duration. Other candidate materials haven't gone though enough tests to show reassuring safety levels (Amlouk, 2010).

\section{Materials optimisation}

\subsection{Primal selection protocols}

Cost and toxicity concerns led to less and less use of Se and Cd-like materials. Additionally, increasing interest in conjoint heat-light conversion took some bad heat-conducting materials out from consideration. Selection protocols are becoming more concentrated on thermal, mechanical and opto-electric performance.

Since thermal conductivity, specific heat and thermal diffusivity has always been considered as material intrinsic properties, while absorbance and reflexivity depend on both material and excitation, there was a need of establishing advanced physical parameters bringing these proprieties together.

\subsection{Opto-thermal analysis}

The Amlouk-Boubaker optothermal expansivity is defined by:

$$
\psi_{\mathrm{AB}}=\frac{D}{\hat{\alpha}}
$$

Where $D$ is the thermal diffusivity and $\hat{\alpha}$ is the effective absorptivity, defined in the next section. 


\subsubsection{The effective absorptivity}

The effective absorptivity $\hat{\alpha}$ is defined as the mean normalized absorbance weighted by $I(\tilde{\lambda})_{\mathrm{AM} 1.5}$, the solar standard irradiance, with $\tilde{\lambda}:$ the normalised solar spectrum wavelength:

$$
\left\{\begin{array}{l}
\tilde{\lambda}=\frac{\lambda-\lambda_{\min }}{\lambda_{\max }-\lambda_{\min }} \\
\lambda_{\min }=200.0 \mathrm{~nm} ; \lambda_{\max }=1800.0 \mathrm{~nm} .
\end{array}\right.
$$

and :

$$
\hat{\alpha}=\frac{\int_{0}^{1} I(\tilde{\lambda})_{\mathrm{AM} 1.5} \times \alpha(\tilde{\lambda}) d \tilde{\lambda}}{\int_{0}^{1} I(\tilde{\lambda})_{\mathrm{AM} 1.5} d \tilde{\lambda}}
$$

where: $I(\tilde{\lambda})_{\mathrm{AM} 1.5}$ is the Reference Solar Spectral Irradiance.

The normalized absorbance spectrum $\alpha(\tilde{\lambda})$ is deduced from the Boubaker polynomials Expansion Scheme BPES (Oyedum et al., 2009; Zhang et al., 2009, 2010a, 2010b; Ghrib et al., 2007; Slama et al., 2008; Zhao et al., 2008; Awojoyogbe and Boubaker, 2009; Ghanouchi et al.,2008; Fridjine et al., 2009 ; Tabatabaei et al., 2009; Belhadj et al., 2009; Lazzez et al., 2009; Guezmir et al., 2009; Yıldırım et al., 2010; Dubey et al., 2010; Kumar, 2010; Agida and Kumar, 2010). According to this protocol, a set of $m$ experimental measured values of the transmittance-reflectance vector: $\left.\left(T_{i}\left(\tilde{\lambda}_{i}\right) ; R_{i}\left(\tilde{\lambda}_{i}\right)\right)\right|_{i=1 . . m}$

versus the normalized wavelength $\left.\tilde{\lambda}_{i}\right|_{i=1 . . m}$ is established. Then the system (4) is set:

$$
\left\{\begin{array}{l}
R(\tilde{\lambda})=\left[\frac{1}{2 N_{0}} \sum_{n=1}^{N_{0}} \xi_{n} \times B_{4 n}\left(\tilde{\lambda} \times \beta_{n}\right)\right] \\
T(\tilde{\lambda})=\left[\frac{1}{2 N_{0}} \sum_{n=1}^{N_{0}} \xi_{n}^{\prime} \times B_{4 n}\left(\tilde{\lambda} \times \beta_{n}\right)\right]
\end{array}\right.
$$

where $\beta_{n}$ are the $4 \mathrm{n}$-Boubaker polynomials $B_{4 \mathrm{n}}$ minimal positive roots $\left(N_{0}\right.$ is a given integer and $\xi_{n}$ and $\xi_{n}^{\prime}$ are coefficients determined through Boubaker Polynomials Expansion Scheme BPES.

Finally, the normalized absorbance spectrum $\alpha(\tilde{\lambda})$ is calculated using the relation (5) :

$$
\alpha(\tilde{\lambda})=\frac{1}{d \sqrt{2}} \sqrt{\left(\ln \frac{1-R(\tilde{\lambda})}{T(\tilde{\lambda})}\right)^{2}+\left(\ln \frac{(1-R(\tilde{\lambda}))^{2}}{T(\tilde{\lambda})}\right)^{2}}
$$

where $d$ is the layer thickness.

The effective absorptivity $\hat{\alpha}$ is calculated using (Eq. 3) and (Eq. 5). 


\subsubsection{The Optothermal expansivity $\psi_{\mathrm{AB}}$}

The Amlouk-Boubaker optothermal expansivity unit is $\mathrm{m}^{3} \mathrm{~s}^{-1}$. This parameter, as calculated in Eq. (1) can be considered either as the total volume that contains a fixed amount of heat per unit time, or a 3D expansion velocity of the transmitted heat inside the material.

\subsubsection{The optimizing-scale 3-D Abacus}

According to precedent analyses, along with the definitions presented in $\S 3.2$, it was obvious that any judicious material choice must take into account simultaneously and conjointly the three defined parameters: the band gap Eg, Vickers Microhardness Hv and The Optothermal Expansivity $\Psi_{\mathrm{AB}}$. The new 3D abacus (Fig. 2) gathers all these parameters and results in a global scaling tool as a guide to material performance evaluation.

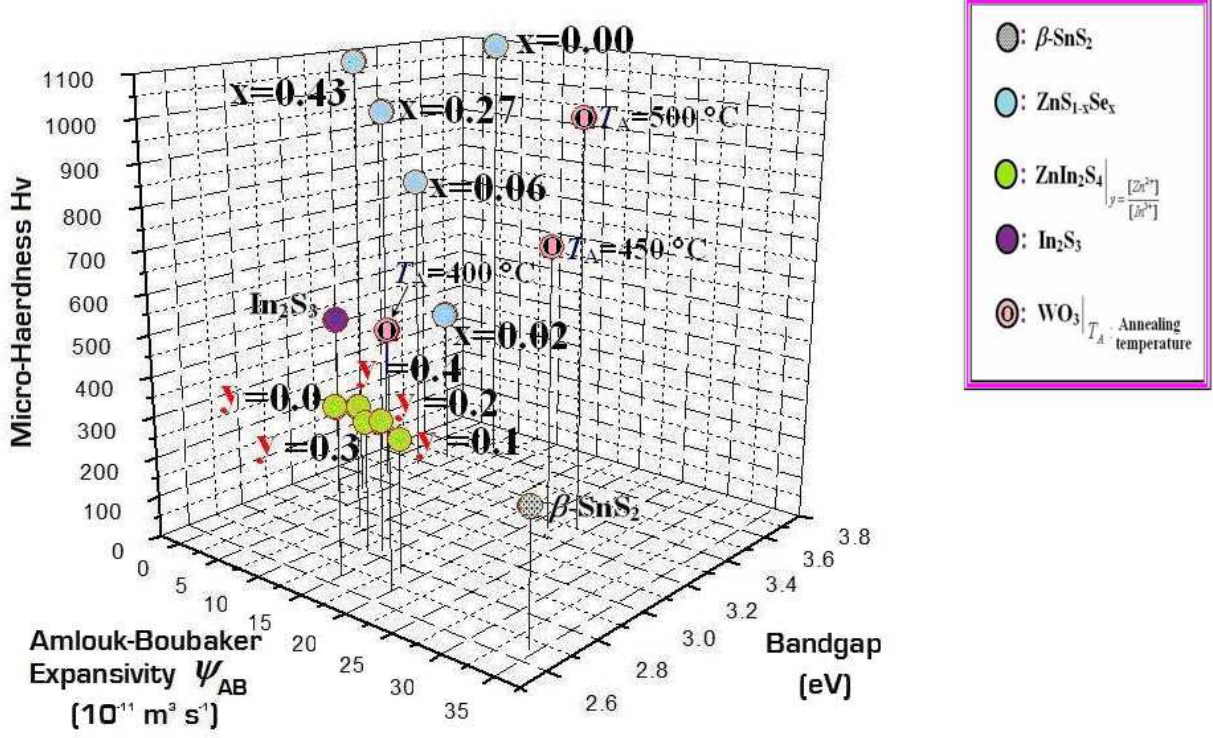

Fig. 2. The 3D abacus

For particular applications, on had to ignore one of the three physical parameters gathered in the abacus. The following $2 \mathrm{D}$ projections have been exploited:

The projection in $\mathrm{Ho}$-Eg plane, which is interesting in the case of a thermally neutral material.

It is the case, i.e. of the $\mathrm{ZnS}_{1-x} \mathrm{Se}_{\mathrm{x}}$ compounds, it is obvious that the consideration of Band gap-Haredness features is mor important than thermal proprieties. The $\mathrm{Eg}$ - Ho projection (Fig. 3) gives relevant information: the selenization process causes drastical loss of hardness in initially hard binary Zn-S material. 


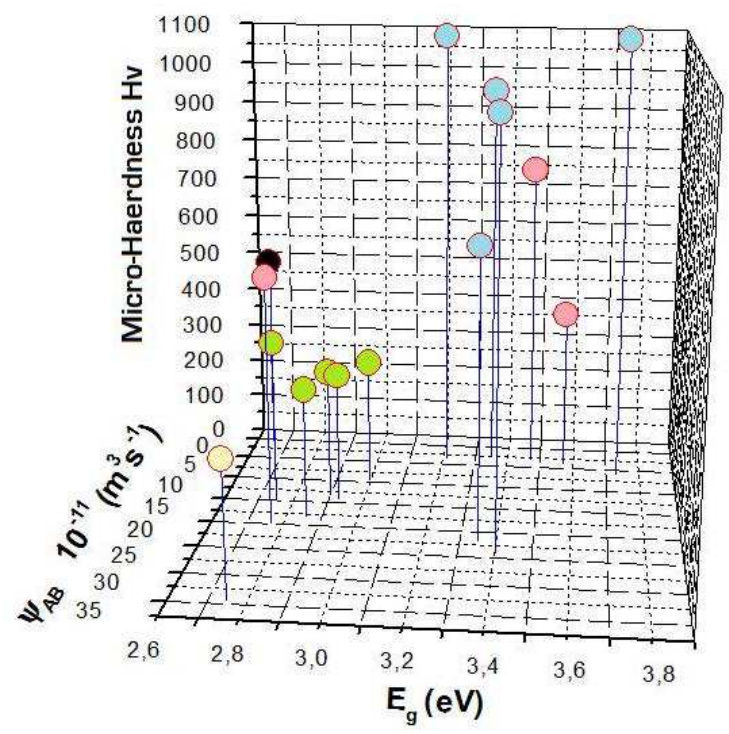

Fig. 3. The 3D abacus (Eg - Ho projection)

This projection in $\Psi_{\mathrm{AB}}-\mathrm{Eg}_{\mathrm{g}}$ plane is suitable for thick layers whose mechanical properties don't contribute significantly to the whole disposal hardness.

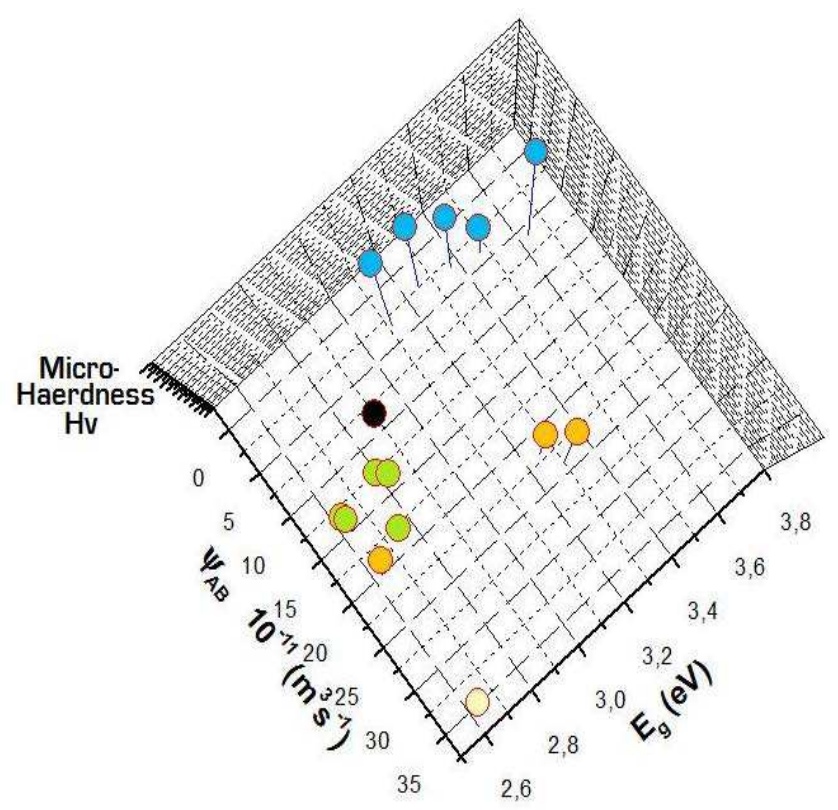

Fig. 4. The 3D abacus ( $\Psi_{\mathrm{AB}}-$ Eg projection) 
The projection in $\Psi_{\mathrm{AB}}-\mathrm{Ho}$ plane is useful for distinguishing resistant and good heat conductor materials, which is the case of the $\mathrm{ZnIn}_{2} \mathrm{~S}_{4}$ materials.

In fact the effect of the Zinc-to-Indium ratio on the values of the Amlouk-Boubaker optothermal expansivity (Fig. 5) is easily observable in this projection (it is equivalent to an expansion of the values of the parameter $\Psi_{\mathrm{AB}}$ into a wide range: [10-20] $10^{-11} \mathrm{~m}^{3} \mathrm{~s}^{-1}$ ).

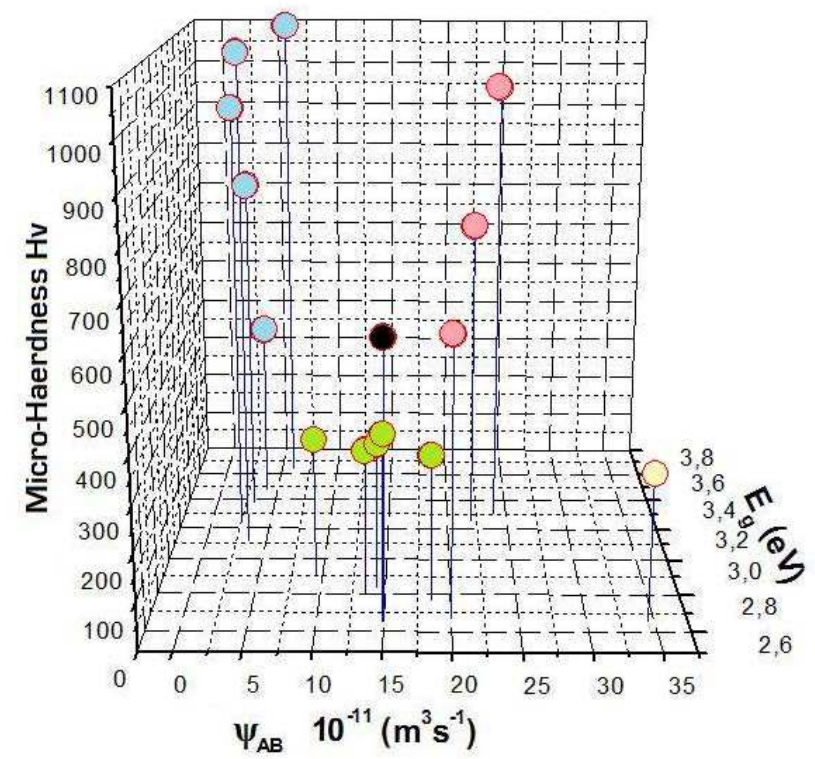

Fig. 5. The 3D abacus ( $\Psi_{\mathrm{AB}}-\mathrm{Ho}$ projection)

\subsection{Investigation of the selected materials}

According to the information given by the 3D abacus (Figures 3-5), some materials have been selected. $\mathrm{ZnO}$ and $\mathrm{ZnO}$-doped layered materials, $\mathrm{SnO}_{2}$ and $\mathrm{SnO}_{2}: \mathrm{F} / \mathrm{SnO}_{2}: \mathrm{F}-\mathrm{SnS}_{2}$ compounds were among the most interesting ones.

\subsubsection{ZnO and ZnO-doped layers}

Zinc oxide $(\mathrm{ZnO})$ is known as one of the most multifunctional semiconductor material used in different areas for the fabrication of optoelectronic devices operating in the blue and ultra-violet (UV) region, owing to its direct wide band gap (3.37 eV) at room temperature and large exciton binding energy (60 meV) (Coleman \& Jagadish, 2006). On the other hand, it is one of the most potential materials for being used as a TCO because of its high electrical conductivity and high transmission in the visible region (Fortunato et al., 2009).

Zinc oxide can be doped with various metals such as aluminium (Benouis et al., 2007) indium (Benouis et al., 2010), and gallium (Fortunato et al., 2008). The conditions of deposition and the choice of the substrate are important for the growth of the films (Benhaliliba et al., 2010). The substrate choosen must present a difference in matching lattice less than $3 \%$ to have good growth of the crystal on the substrate (Teng et al., 2007; Romeo et 
al., 1998). ZnO (both doped and undoped) is currently used in the copper indium gallium diselenide (CIGS, or Cu (In, Ga)Se2) thin-film solar cell (Wellings et al., 2008; Haung et al., 2002). $\mathrm{ZnO}$ is also promising for the application in the electronic and sensing devices, either as field effect transistors (FET), light sensor, gas and solution sensor, or biosensor.

In addition to its interesting material properties motivating research of $\mathrm{ZnO}$ as semiconductor, numerous applications of $\mathrm{ZnO}$ are well established. The world usage of $\mathrm{ZnO}$ in 2004 was beyond a million tons in the fields like pharmaceutical industry (antiseptic healing creams, etc.), agriculture (fertilizers, source of micronutrient zinc for plants and animals), lubricant, photocopying process and anticorrosive coating of metals.

In electronic engineering, Schottky diode are the most known ZnO-based unipolar devices. The properties of rectifying metal contacts on $\mathrm{ZnO}$ were studied for the first time in the late 60ties (Mead, 1965; Swank, 1966; Neville \& Mead, 1970) while the first Schottky contacts on $\mathrm{ZnO}$ thin films were realized in the 80ties (Rabadanov et al., 1981; Fabricius et al., 1986).

The undoped and doped $\mathrm{ZnO}$ films grow with a hexagonal würtzite type structure and the calculated lattice parameters (a and c) are given in Table 1 (Benhaliliba et al. 2010).

\begin{tabular}{|c|c|c|c|c|c|c|c|c|c|}
\hline Nature & Grain Size $(\AA ̊)$ & Int. (\%) & d (Å) & $2 \theta\left({ }^{\circ}\right)$ & $\begin{array}{c}\text { Angle } \\
\text { Shift }\left(^{\circ}\right)\end{array}$ & TC & a $(\AA)$ & c $(\AA)$ & $\left(\mathrm{c}-\mathrm{c}_{0}\right) / \mathrm{c}_{0}\left(\times 10^{-5}\right)$ \\
\hline \multicolumn{10}{|l|}{ Undoped } \\
\hline (100) & 217 & 6.3 & 2.81 & 31.78 & 0.009 & 0.50 & \multirow{3}{*}{3.24} & \multirow{3}{*}{5.20} & -61.4 \\
\hline$(002)$ & 358 & 25.7 & 2.60 & 34.44 & -0.019 & 2.33 & & & \\
\hline (101) & 254 & 19.4 & 2.47 & 36.24 & -0.008 & 1.67 & & & \\
\hline \multicolumn{10}{|l|}{$\mathrm{IZO}$} \\
\hline$(100)$ & 239 & 100 & 2.81 & 31.80 & -0.050 & 2.24 & \multirow{3}{*}{3.24} & \multirow{3}{*}{5.20} & -3.84 \\
\hline (002) & 211 & 53.5 & 2.60 & 34.42 & -0.019 & 1.19 & & & \\
\hline (101) & 195 & 85.5 & 2.47 & 36.28 & $-0,028$ & 1.95 & & & \\
\hline \multicolumn{10}{|l|}{$\mathrm{AZO}$} \\
\hline (100) & 206 & 70.7 & 2.81 & 31.80 & -0.011 & 1.52 & \multirow{3}{*}{3.24} & \multirow{3}{*}{5.20} & -115.23 \\
\hline$(002)$ & 225 & 70.5 & 2.60 & 34.46 & -0.039 & 1.48 & & & \\
\hline (101) & 195 & 100 & 2.47 & 36.28 & -0.028 & 2.13 & & & \\
\hline
\end{tabular}

Table 1.

Many significant differences were observed for the undoped, Al- and In-doped $\mathrm{ZnO}$ thin films. The films with low thickness $(150 \mathrm{~nm})$ have a random orientation with several peaks as reported by Wellings et al. (2008), Ramirez et al. (2007) and Abdullah et al. (2009). The same kind of growth was obtained by Tae et al. (1996) for $150 \mathrm{~nm}$ thick films. Whereas on FTO, the predominant $\mathrm{ZnO}$ film grew to a thickness of $200-300 \mathrm{~nm}$ as stated by Schewenzer et al. (2006). Figures (6-8) give some information about some information about $\mathrm{ZnO}$ and $\mathrm{ZnO}$-doped layers. 

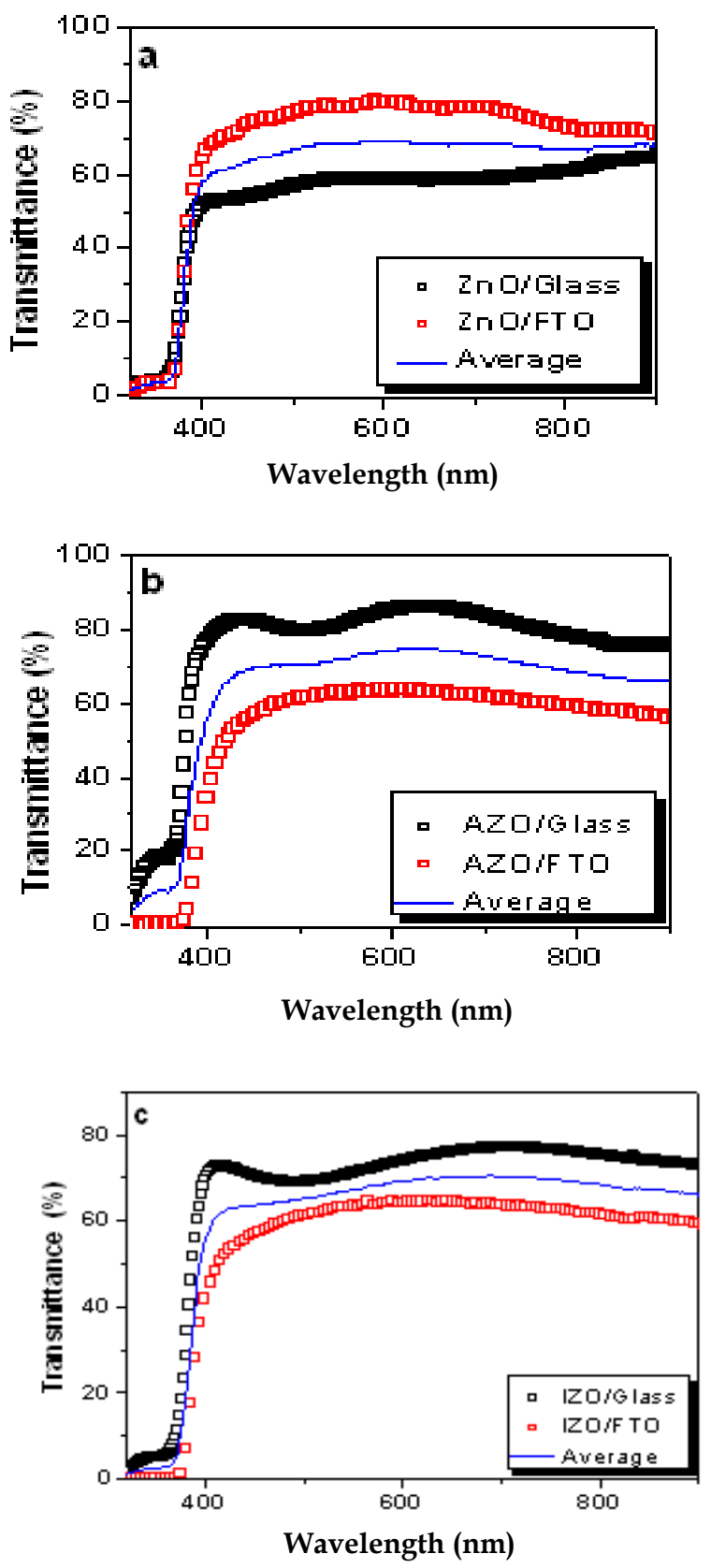

Fig. 6. Transmittance spectra, $\mathrm{ZnO} /$ Glass and ZnO/FTO (a), AZO/Glass and AZO/FTO (b), IZO/Glass and IZO/FTO (c). 


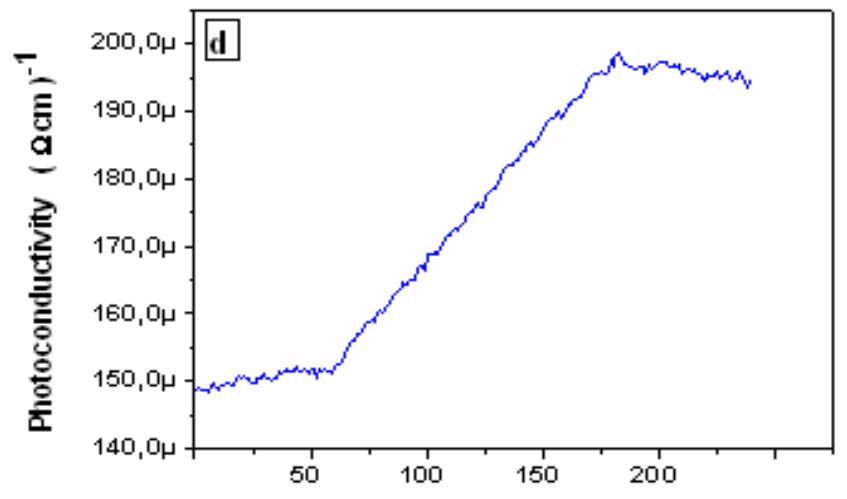

Time (s)

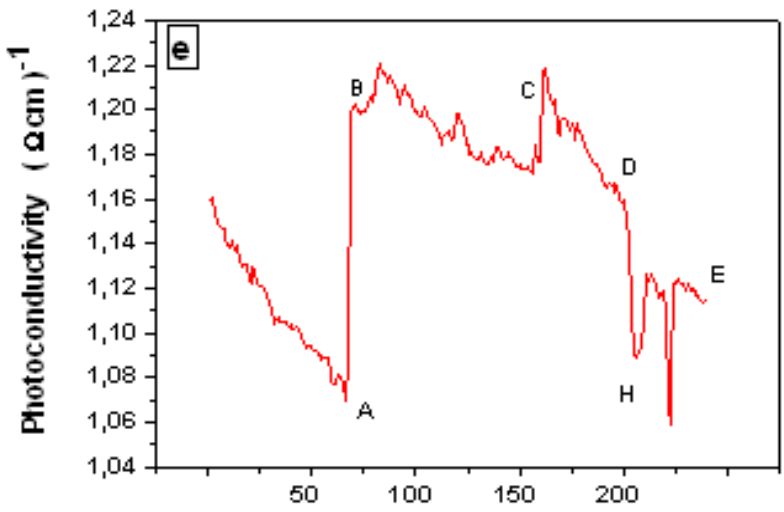

Time (s)

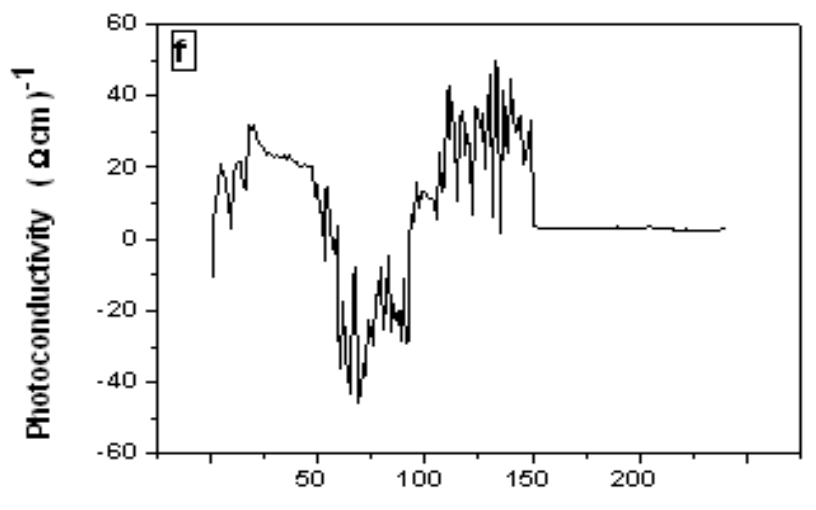

Time (s)

Fig. 7. Photoconductivity spectra versus time of ZnO/FTO (d), AZO/FTO (e), IZO/FTO (f). 

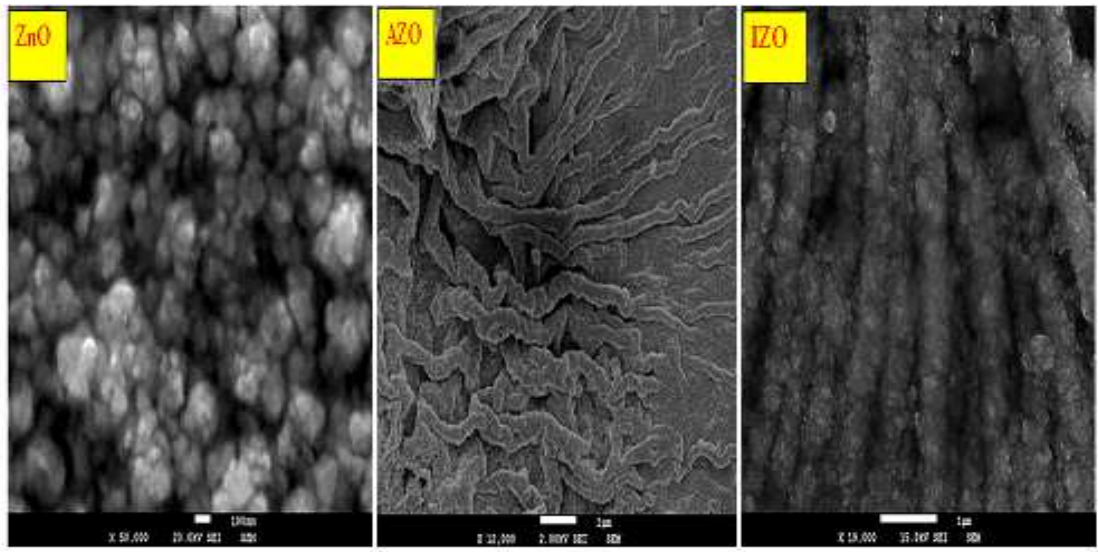

Fig. 8. SEM micrographs for (a) ZnO, (b) AZO and (c) IZO films, (bottom) white horizontal dashes indicate the scale (100 $\mathrm{nm}(\mathrm{ZnO}), 1 \mu \mathrm{m}(\mathrm{AZO}$ and IZO)..

\subsection{2 $\mathrm{SnO}_{2}: \mathrm{F}_{-} \mathrm{SnS}_{2}$ gradually grown layers}

Tin oxide $\left(\mathrm{SnO}_{2}\right)$ is an $n$-type VIIII oxide semiconductor with a wide band gap $(E \mathrm{~g}=3.6 \mathrm{eV})$. Because of its good opto-electrical properties, and its ability to induce a high degree of charge compensation, it is widely used as a functional material for the optoelectronic devices, gas sensor, ion sensitive field effect transistors, and transparent coatings for organic light emitting diodes (Onyia \& Okeke, 1989; Wang et al., 2006; Lee \& Park, 2006; Yamada et al., Kane \& Schweizer,1976).

In the last decades, pure and doped tin oxide compounds, prepared by several techniques (Manorama et al., 1999; Bruno et al., 1994; Brinzari et al., 2001; Wang et al., 2002) have been used for the preparation of high performance gas sensing and light emitting devices layers ( Barsan, 1994; Goepel \& Schierbaum, 1995; Ramgir et al. ,2005).

$\mathrm{SnO}_{2}$ thin films are generally prepared using methanol $\mathrm{CH}_{4} \mathrm{O}: 1.0 \mathrm{~L}$, demineralised water and anhydrous tin tetrachloride $\mathrm{SnCl}_{4}$. Formation of pure $\mathrm{SnO}_{2}$ is resulting from the endothermic reaction:

$$
\mathrm{SnCl}_{4}+2 \mathrm{H}_{2} \mathrm{O} \stackrel{\text { methanol, } 440^{\circ} \mathrm{C}}{\longrightarrow} \mathrm{SnO}_{2}+4 \overline{\mathrm{HCl}}
$$

Approximately $0.9 \mu$ m-thick $\mathrm{SnO}_{2}$ thin films are generally deposited on glass, under an approximated substrate temperature $T_{\mathrm{s}}=440^{\circ} \mathrm{C}$.

XRD patterns of the as-grown $\mathrm{SnO}_{2}$ films are shown in Fig. 9. Diagram analysis shows that the layers present a first set of (110)-(101)-(200) X-ray diffraction peaks followed by more important pair (211)-(301). According to JCDPS 88-0287 (2000) standards, these patterns refer to tetragonal crystalline structure.

It was reported by Yakuphanoglu (2009) and Khandelwal et al. (2009)that $\mathrm{SnO}_{2}$ films structure depends wholly on elaboration technique, substrate material and thermal treatment conditions. This feature was also discussed by Purushothaman et al. (2009) and Kim et al. (2008) who presented temperature-dependent structure alteration of the $\mathrm{SnO}_{2}$ layers.

Atomic force microscopy (AFM) 3D images of the $\mathrm{SnO}_{2}$ are presented in Fig. 10.

The layers present a pyramidal-clusters rough structure, which is characteristic to many Snlike metal oxides. This observation confirms the XRD results. 


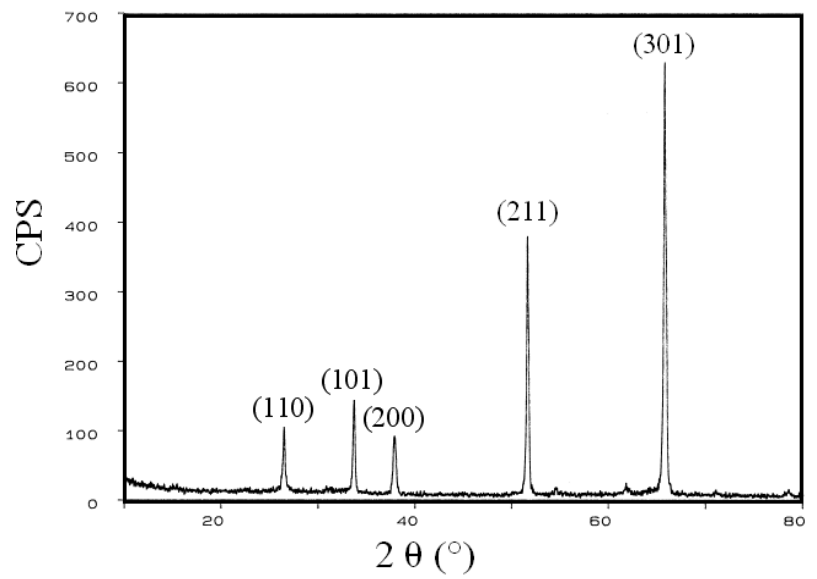

Fig. 9. XRD Diagram of $\mathrm{SnO}_{2}$ thin layers prepared at $T_{\mathrm{s}} 440{ }^{\circ} \mathrm{C}$.

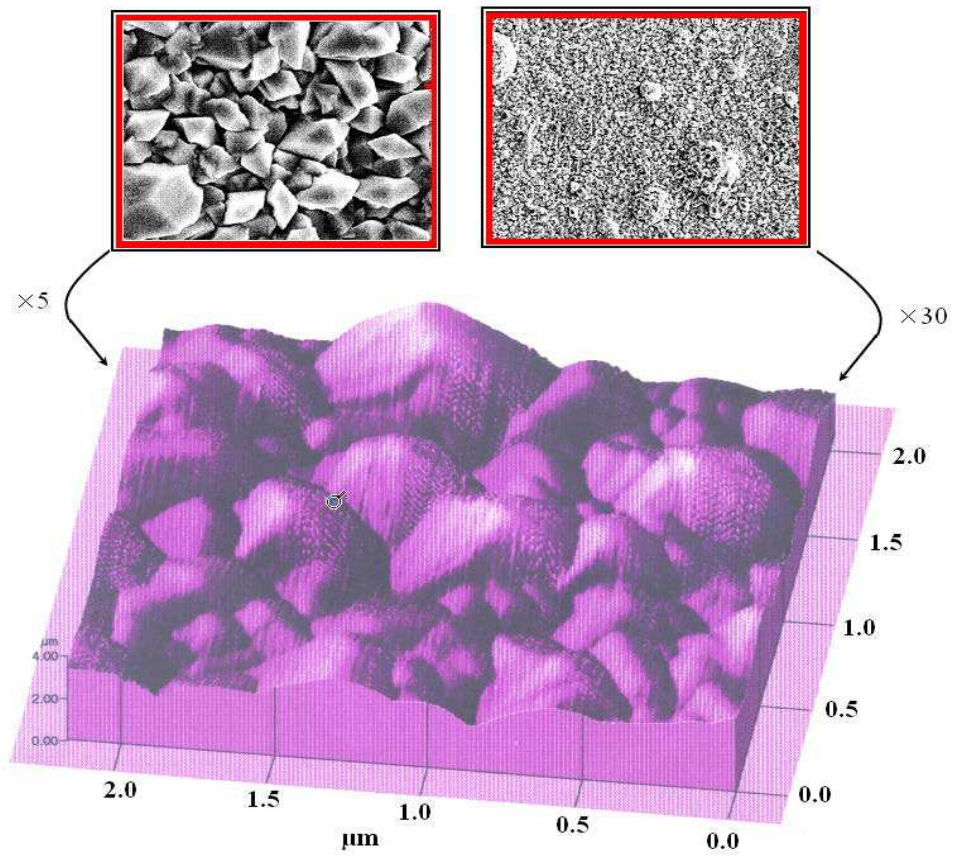

Fig. 10. $\mathrm{SnO}_{2}$ layers 3D and 2D surface topography 2D (top) and 3D (bottom).

$\mathrm{SnO}_{2}: \mathrm{F}-\mathrm{SnS}_{2}$ gradually grown layers have as intermediate precursors $\mathrm{SnO} 2: \mathrm{F}$ layers obtained by spray pyrolysis on glass substrates according to the coupled reactions :

$$
\left(\mathrm{SnCl}_{4}, 5 \mathrm{H}_{2} \mathrm{O}\right)_{\mathrm{n}}+2 \mathrm{nH}_{2} \mathrm{O} \underset{\text { Carrier gas }}{\stackrel{\text { Soray }}{\longrightarrow} \mathrm{nnCl}}+7 \mathrm{n} \overrightarrow{\mathrm{H}_{2} \mathrm{O}}
$$


and

$$
\mathrm{nSnCl}+\mathrm{n}\left(\mathrm{NH}_{4}^{+}, \mathrm{F}^{-}\right)+2 \mathrm{n} \mathrm{H}_{2} \mathrm{O} \underset{\text { methanol }}{\stackrel{440^{\circ} \mathrm{C}}{\longrightarrow}} \mathrm{n} \underset{\mathrm{SnO}_{2}: \mathrm{F}}{\imath}+4 \overrightarrow{\mathrm{HCl}}+\mathrm{n} \overrightarrow{\mathrm{NH}}_{3}+\frac{\mathrm{n}}{2} \overrightarrow{\mathrm{H}_{2}}
$$

In the second reaction, ammonium florid acts on the deposited (and heated) tin tetrachloride by incorporation process due to ionic close electro-negativity and dimension ( $\mathrm{F}^{-}$and $\mathrm{O}^{2-}$ radii ratio is around 0.96). The obtained layers are n-type (Fig 11-a)

Hence, the first step of the protocol is indeed elaboration of the precursor $\mathrm{SnO}_{2}$ : $\mathrm{F}$ layer. In the second step, this layer is subjected to local annealing in a highly sulfured atmosphere (Fig 11-b). Under specific experimental conditions (Temperature, pressure, exposure time) $\mathrm{SnS}_{2}$ compound appears selectively at the top of the precursor $\mathrm{SnO}_{2}: \mathrm{F}$ layer. This obtained mini-layer is n-type (fig 11-b).

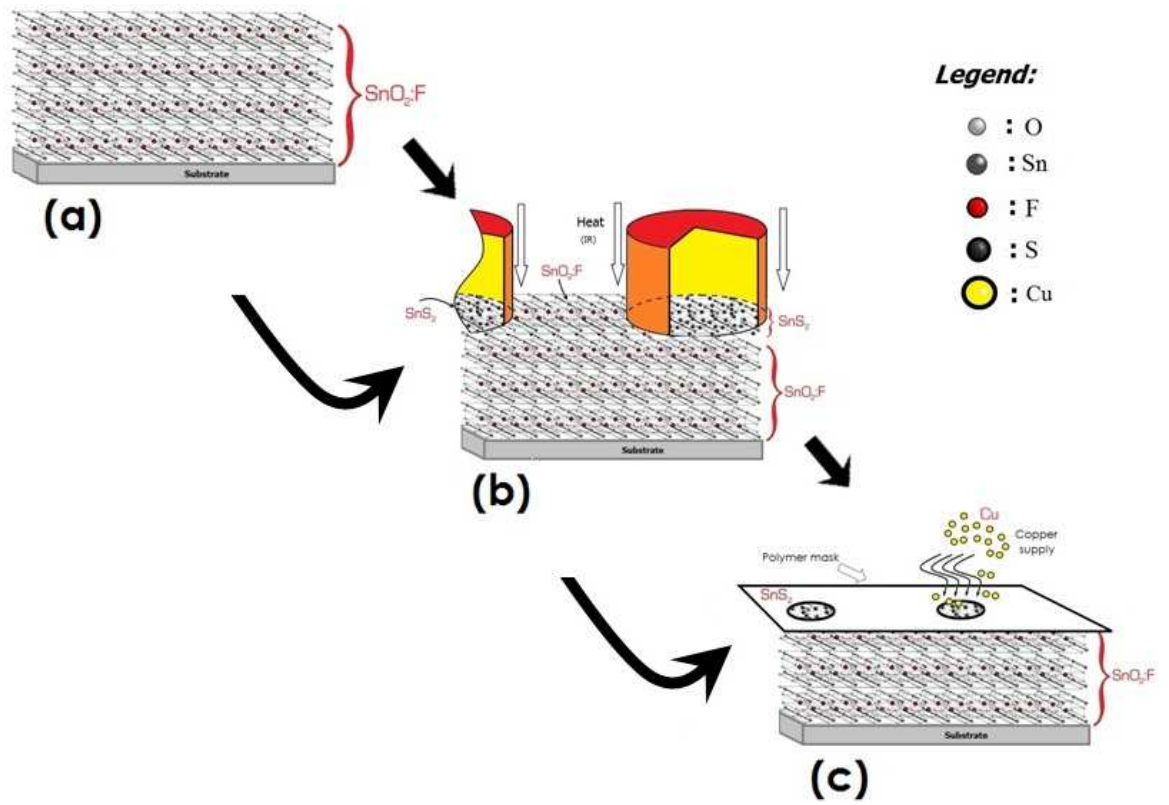

Fig. 11. TCO monolayer-grown: cell elaboration protocol

Finally, a neutral masking sheet is applied to the free surface in order to deposit copper $(\mathrm{Cu})$ by evaporation, controlled dipping or even direct mechanical spotting. Due to the metallic diffusive properties, a multiphase $\mathrm{CuSnS}\left(\mathrm{Cu}_{2} \mathrm{SnS}_{3}, \mathrm{Cu}_{3} \mathrm{SnS}_{4}, \mathrm{Cu} . ..\right)$ conducting compound appears at the free surfaces (Fig 11-c). This compound has been verified to have better mechanical performance than CuInS.

\subsubsection{A sketch of the thermally optimized new monolayer grown cell}

The first prototype of the proposed TCO monolayer-grown Solar cell is presented in Figure 12. The procedure can be applied to other oxides, namely $\mathrm{Sb}_{\mathrm{x}} \mathrm{O}_{\mathrm{y}}, \mathrm{Sb}_{\mathrm{x}} \mathrm{S}_{\mathrm{y}} / \mathrm{MSbO}$ $(\mathrm{M}=\mathrm{Cu}, \mathrm{Ag}, .$.$) hetero-junction.$ 
It has been experimented that n-type can be locally and partially transformed into $\mathrm{p}-\mathrm{WS}_{2}$, which results in a $\mathrm{WO}_{3} / \mathrm{WS}_{2}$ heterojunction, using the same sulfuration procedure detailed above.

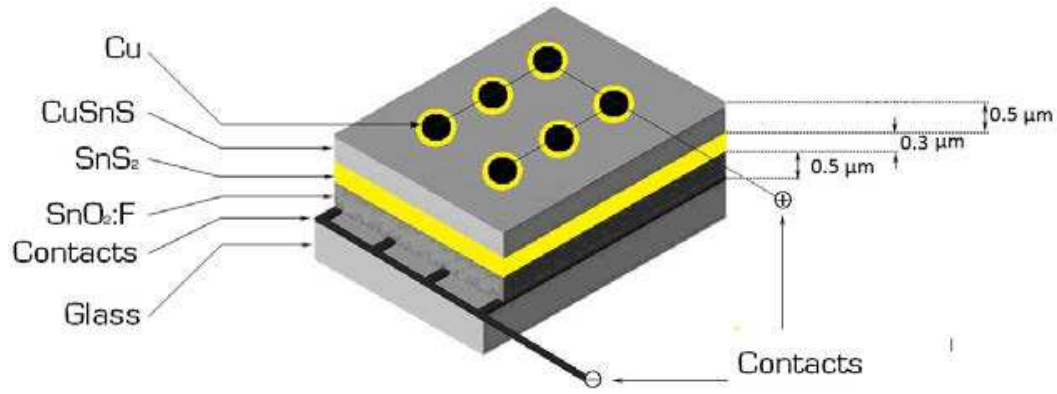

Fig. 12. TCO monolayer-grown Solar cell

The case of $\mathrm{ZnO}$ has been experimented but raised some problems, in fact it has been recorded that sulfuration process is never complete, and that an unexpected mixture $(\mathrm{ZnO})_{\mathrm{x}}(\mathrm{ZnS})_{\mathrm{y}}$ takes place.

\section{Conclusion}

In this chapter, a new physical parameter has been proposed as a guide for optimizing the recently implemented oxide monolayer spray-grown solar cells. This parameter led to the establishment of a 3D (bangap Eg-Vickers Microhardness Ho - Optothermal Expansivity $\Psi_{\mathrm{AB}}$ ) abacus. Thanks to optimizing features, some interesting materials have been selected for an original purpose: The TCO monolayer-grown Solar cell. The first prototype of the proposed TCO monolayer-grown Solar cell has been presented and commented. The perspective of using other oxides, namely $\mathrm{Sb}_{\mathrm{x}} \mathrm{O}_{\mathrm{y}}, \mathrm{Sb}_{\mathrm{x}} \mathrm{S}_{\mathrm{y}} / \mathrm{MSbO}(\mathrm{M}=\mathrm{Cu}, \mathrm{Ag}, .$.$) has been discussed.$

\section{References}

Abdullah, H.N.P.Ariyanto, S.Shaari, B.Yuliarto and S.Junaidi, Am. J. Eng. and Appl. Sc. 2 (2009) 236-240.

Abe, Y. \& Ishiyama N., (2006). Titanium-doped indium oxide films prepared by DC magnetron sputtering using ceramic target. J. Mater. Sci. 41, pp.7580-7584

Agida, M., Kumar, A. S., 2010. A Boubaker Polynomials Expansion Scheme Solution to Random Love's Equation in the Case of a Rational Kernel , J. of Theoretical Physics 7,319.

Amlouk, A.; Boubaker K.\& Amlouk M., (2010). J. Alloys Compds, 490,pp. 602-604.

Awojoyogbe, O.B., Boubaker, K., 2008. A solution to Bloch NMR flow equations for the analysis of homodynamic functions of blood flow system using $\mathrm{m}$ - Boubaker polynomials. Curr. Appl. Phys. 9, 278-283.

Bandara, J. \& Tennakone, K. J. (2001). Colloid Interface Sci. 236, pp. 375-382.

Barsan, N. Sens. Actuators, B, Chem. 17 (1994) 241.

Bauer, C.; Boschloo, G., Mukhtar, E. \& Hagfeldt, A. (2001). J. Phys. Chem. B 105,pp. 5585-5591.

Belhadj, A., Onyango, O., Rozibaeva, N., 2009. Boubaker polynomials expansion schemerelated heat transfer investigation inside keyhole model. J. Thermo- phys. Heat Transfer 23, 639-640. 
Benhaliliba, C. E. Benouis, M. S. Aida, F. Yakuphanoglu, A. Sanchez Juarez, J Sol-Gel Sci Technol (2010) 55:335-342 DOI 10.1007/s10971-010-2258-x.

Benhaliliba, C.E. Benouis, M.S. Aida, A. Sanchez Juarez, F. Yakuphanoglu, A. Tiburcio Silver, J. Alloys Compd. 506 (2010) 548-553.

Benouis, C.E. ; Benhaliliba, M. , Sanchez Juarez, A., Aida, M.S., F.Yakuphanoglu, F., (2010). Journal of Alloys and Compounds 490, pp. 62-67.

Benouis C.E., M. Benhaliliba, F. Yakuphanoglu, A. Tiburcio Silver, M.S. Aida, A. Sanchez Juarez, Synthetic Metals (2011). D.O.I. 10.1016/ J. Synthmet.2011.04.017.

Benouis, C.E. ; Sanchez-Juarez, A., Aida, M.S., (2007). Phys. Chem. News, 35, pp. 72-79.

Brinzari V., G. Korotcenkov, V. Golovanov, Thin Solid Films 391 (2001) 167.

Bruno, L.C. Pijolat, R. Lalauze, Sens. Actuators, B, Chem. 18-19 (1994) 195.

Coleman, V. A. \& Jagadish C., (2006). Basic Properties and Applications of ZnO, and: chapter1 Zinc Oxide Bulk, Thin Films and Nanostructures C. Jagadish and S. Pearton Elsevier limited.

Dubey, B., Zhao, T.G., Jonsson, M., Rahmanov, H. 2010. A solution to the acceleratedpredator-satiety Lotka-Volterra predator-prey problem using Boubaker polynomial expansion scheme. J. Theor. Biology 264, 154-160.

Fabricius H, Skettrup T, Bisgaard P. Appl Opt 1986;25:2764-7.

Fortunato, E.; Gonçalves, A., Pimentel, A., Barquinha, P., Gonçalves, G., Pereira, L., Ferreira, I. \& Martins, R., (2009). Appl. Phys. A Mat. Sci. Proc. 96, pp.197-205.

Fortunato, E.; Raniero, L., Silva, L,. Gonçalves, A., Pimentel, A., Barquinha, P., Aguas, H., Pereira, L., Gonçalves, G., Ferreira, I., Elangovan, E., Martins, R., (2008). Sol. En. Mat. And Sol. Cells 92, pp.1605-1610.

Fridjine, S., Amlouk, M., 2009. A new parameter: an ABACUS for optimizing functional materials using the Boubaker polynomials expansion scheme. Mod. Phys. Lett. B 23, 2179-2182.

Ghanouchi, J., Labiadh, H., Boubaker, K., 2008. An Attempt to solve the heat transfer equation in a model of pyrolysis spray using 4q-order Boubaker polynomials. Int. J. Heat Technol. 26, 49-53.

Ghrib, T., Boubaker, K., Bouhafs, M., 2008. Investigation of thermal diffusivitymicrohardness correlation extended to surface-nitrured steel using Boubaker Ginot, V. \& Hervé, J. C. ,1994, Estimating the parameters of dissolved oxygen dynamics in shallow ponds, Ecol. Model. 73, 169-187.

Goepel, W. Schierbaum, K.D. Sens. Actuators, B, Chem. 26 (1995) 1.

Guezmir, N., Ben Nasrallah, T., Boubaker, K., Amlouk, M., Belgacem, S., 2009. Optical modeling of compound CuInS2 using relative dielectric function approach and Boubaker polynomials expansion scheme BPES. J. Alloys Compd. 481, 543-548.

Haung F.J, Rudmann, D., Bilger, G., Zogg, H., Tiwari, A.N., (2002) Thin Solid Films 403-404, pp. 293-296.

He, J.; Lindstrom, H., Hagfeldt, A. \& Lindquist, S.E. (1999). J. Phys. Chem. B 103, pp. 8940-8951.

Kane, J. H.P. Schweizer, J. Electrochem. Soc. 123 (1976) 270.

Kay, A. \& Gratzel, M. (2002). Chem. Mater 14, pp. 2930-2938.

Khandelwal, R. A. Pratap Singh, A. Kapoor, S. Grigorescu, P. Miglietta, N. Evgenieva Stankova, A. Perrone, Optics \& Laser Tech. 41 (2009) 89

Kim, H. H. Park, H. J. Chang, H. Jeon, H. H. Park, Thin Solid Films, 517(2008) 1072

Kumar, A. S., 2010. An analytical solution to applied mathematics-related Love's equation using the Boubaker Polynomials Expansion Scheme, Journal of the Franklin Institute 347, 1755.

Lee, S.Y. B.O. Park, Thin Solid Films 510 (2006) 154.

Lim, J. H.; Yang E.-J., Hwang D.K., Yang J.H. (2005). Highly transparent and low resistance gallium-doped indium oxide contact to p-type GaN. Appl. Phys. Lett. 87,pp. 1-3 
Manorama, S.V. C.V.G. Reddy, V.J. Rao, Nanostruct. Mater. 11 (1999) 643.

Mead CA. Phys Lett (1965). Pp.18-218.

Nasr, C.; Kamat, P.V.\& Hotchandani, S. J. (1998). Phys. Chem. B 102, pp.10047-10052.

Neville RC, Mead CA. J Appl Phys 1970;41:3795.

Onyia, A.I. C.E. Okeke, J. Phys. D: Appl. Phys. 22 (1989) 1515.

Oyodum, O.D., Awojoyogbe, O.B., Dada, M., Magnuson, J., 2009. On the earliest definition of the Boubaker polynomials. Eur. Phys. J. Appl. Phys. 46, 21201-21203.

Palomares, E.; Cliford, J.N., Haque, S.A., Lutz, T.\& Durrant, J.R. (2003). J. Am. Chem. Soc 125 , pp. $475-481$.

Purushothaman, K.K. M. Dhanashankar, G. Muralidharan, Current App. Physics 9 (2009) 67

Rabadanov RA, Guseikhanov MK, Aliev IS, Semiletov SA. Fizika (Zagreb)1981;6:72.

Ramgir, N.S. Mulla, I.S. Vijayamohanan, K.P. J. Phys. Chem., B 109 (2005) 12297.

Ramirez, D.D.Silva, H.Gomez, G.Riveros, R.E.Marotti, E.D.Dalchiele, Solar Energy Materiels and Solar Cells 31 (2007) 1458-1451.

Redmond, G.; Fitzmaurice, D. \& Gratzel, M. (1994). Chem. Mater. 6, pp. 686-689.

Romeo, A.; Tiwari, A.N., \& Zogg, H., 2nd World Conference and Exhibition on Photovoltaic Solar Energy Conversion 6-10 July 1998 Hofburg Kongresszentru, Vienna Austria.

Sayama, K.; Sugihara, H. \& Arakawa H.(1998). Chem. Mater. 10, 3825-3830.

Schewenzer, B.J.R.Gommm and D.E.Morse, Langmuir 22 (2006) 9829-9831.

Slama, S., Bessrour, J., Bouhafs, M., BenMahmoud, K. B., 2009a .Numerical distribution of temperature as a guide to investigation of melting point maximal front spatial evolution during resistance spot welding using Boubaker polynomials. Numer. Heat Transfer Part A 55,401-408.

Slama, S., Boubaker, K., Bessrour, J., Bouhafs, M., 2009b. Study of temperature 3D profile during weld heating phase using Boubaker polynomials expansion. Thermochim. Acta 482, 8-11.

Slama, S., Bouhafs, M., Ben Mahmoud, K.B., Boubaker, A., 2008. Polynomials solution to heat equation for monitoring A3 point evolution during resistance spot welding. Int. J. Heat Technol. 26, 141-146.

Swank RK. Phys Rev 1966;153:844.

Tabatabaei, S., Zhao, T., Awojoyogbe, O., Moses, F., 2009. Cut-off cooling velocity profiling inside a keyhole model using the Boubaker polynomials expansion scheme. Heat Mass Transfer 45, 1247-1251.

TaeYoung Ma, Sang Hyun Kim, Hyun Yul Moon, Gi Cheol Park, Young Jin Kim, Ki Wan Kim, J.Appl.Phys. 35(1996) 6208-6211.

Teng, X.; Fan, H., Pan, S., Ye, C., Li, G., (2007). Materials letters 61, pp. 201-204.

Tennakone, K.; Kumara, G. R. R. A., Kottegoda, I. R. M. \& Perera, V.P.S. (1999). J. Chem. Soc. Chem. Commun. 99, pp. 15-21.

Wang, H.C.Y. Li, M.J. Yang, Sens. Actuators B 119 (2006) 380.

Wang, Y. C. Ma, X. Sun, H. Li, Nanotechnology 13 (2002) 565.

Wellings, J.S.; Chaure, N.B., Heavens, S.N., Dharmadasa, I.M., (2008). Thin Solid Films, 516, pp. 3893-3898.

Wellings, J.S.N.B.Chaure, S.N.Heavens, I.M.Dharmadasa, Thin Solid Films, 516 (2008) 3893-3898.

Wu, L. Z.; Tian W.\& Jiang X. T. (2005). Silicon-based solar cell system with a hybrid PV module. Solar Energy Materials and Solar Cells. 87, pp.637-645

Yakuphanoglu, F. Journal of Alloys and Compounds, 470 (2009) 55

Yamada Y., K. Yamashita, Y. Masuoka, Y. Seno, Sens. Actuators B 77 (2001) 12.

Zhao, T.G., Wang, Y.X., Ben Mahmoud, K.B., 2008. Limit and uniqueness of the BoubakerZhao polynomials imaginary root sequence. Int. J. Math. Comput. 1, 13-16. 


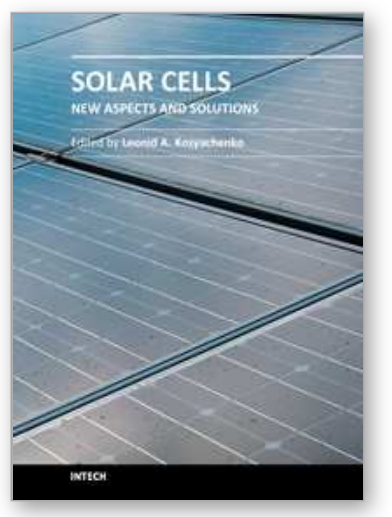

\author{
Solar Cells - New Aspects and Solutions \\ Edited by Prof. Leonid A. Kosyachenko
}

ISBN 978-953-307-761-1

Hard cover, 512 pages

Publisher InTech

Published online 02, November, 2011

Published in print edition November, 2011

The fourth book of the four-volume edition of 'Solar cells' consists chapters that are general in nature and not related specifically to the so-called photovoltaic generations, novel scientific ideas and technical solutions, which has not properly approved. General issues of the efficiency of solar cell and through hydrogen production in photoelectrochemical solar cell are discussed. Considerable attention is paid to the quantum-size effects in solar cells both in general and on specific examples of super-lattices, quantum dots, etc. New materials, such as cuprous oxide as an active material for solar cells, AlSb for use as an absorber layer in $p$-i-n junction solar cells, InGaAsN as a promising material for multi-junction tandem solar cells, InP in solar cells with MIS structures are discussed. Several chapters are devoted to the analysis of both status and perspective of organic photovoltaics such as polymer/fullerene solar cells, poly( $p$-phenylene-vinylene) derivatives, photovoltaic textiles, photovoltaic fibers, etc.

\title{
How to reference
}

In order to correctly reference this scholarly work, feel free to copy and paste the following:

M. Benhaliliba, C.E. Benouis, K. Boubaker, M. Amlouk and A. Amlouk (2011). A New Guide to Thermally Optimized Doped Oxides Monolayer Spray-Grown Solar Cells: The Amlouk-Boubaker Optothermal Expansivity 4AB, Solar Cells - New Aspects and Solutions, Prof. Leonid A. Kosyachenko (Ed.), ISBN: 978-953-307-761-1, InTech, Available from: http://www.intechopen.com/books/solar-cells-new-aspects-and-solutions/a-new-guideto-thermally-optimized-doped-oxides-monolayer-spray-grown-solar-cells-the-amlouk-boubake

\section{INTECH}

open science | open minds

\section{InTech Europe}

University Campus STeP Ri

Slavka Krautzeka 83/A

51000 Rijeka, Croatia

Phone: +385 (51) 770447

Fax: +385 (51) 686166

www.intechopen.com

\section{InTech China}

Unit 405, Office Block, Hotel Equatorial Shanghai

No.65, Yan An Road (West), Shanghai, 200040, China

中国上海市延安西路65号上海国际贵都大饭店办公楼 405 单元

Phone: +86-21-62489820

Fax: $+86-21-62489821$ 
(C) 2011 The Author(s). Licensee IntechOpen. This is an open access article distributed under the terms of the Creative Commons Attribution 3.0 License, which permits unrestricted use, distribution, and reproduction in any medium, provided the original work is properly cited. 